\title{
Quality of Human Urine Used as Fertilizer: Case of an Ecological Sanitation System in Ouagadougou Peri-Urban Areas-Burkina Faso
}

\author{
Joseph M. Makaya1, Aly Savadogo¹, Marius K. Somda', Jean-Baptiste Bour², Nicolas Barro, \\ Alfred S. Traoré ${ }^{1}$ \\ ${ }^{1}$ Research Center for Biological, Food and Nutritional Sciences, Research and Training Unit, Life and Earth \\ Sciences, University of Ouagadougou, Ouagadougou, Burkina Faso. \\ ${ }^{2}$ Laboratory of Virology, National Reference Center for Enteric Viruses, University Hospital of Dijon, \\ Dijon, France \\ Email: makaya.joseph7@gmail.com
}

Received 23 January 2014; revised 23 February 2014; accepted 21 March 2014

Copyright (C) 2014 by authors and Scientific Research Publishing Inc.

This work is licensed under the Creative Commons Attribution International License (CC BY). http://creativecommons.org/licenses/by/4.0/

(c) (i) Open Access

\section{Abstract}

The use in agriculture of excreta from urine-diversion toilets can be an alternative solution to the lack of sanitation and high costs of mineral fertilizers inherent to developing countries. The objective of this study was to evaluate the hygienic quality of urine used as fertilizer through an ecological sanitation system in Ouagadougou peri-urban areas. Chemical and microbiological analyses were performed in urine samples taken before and after thirty (30) days of storage in jerry cans exposed to sunlight. The concentrations of $7.0 \mathrm{~g} / \mathrm{l} ; 3.5$ and $9.6 \mathrm{~g} / \mathrm{l}$ of ammonia nitrogen for mean, minimum and maximum respectively, are obtained in unstored urine samples. These concentrations did not practically vary with the storage. On average, values of other chemical parameters analyzed in stored urine were as follows: $\mathrm{pH}, 8.8$; phosphorus $(\mathrm{P}), 0.3 \mathrm{~g} / \mathrm{l}$; potassium $(\mathrm{K}), 1.9 \mathrm{~g} / \mathrm{l}$; total dissolved solids (TDS), $21.0 \mathrm{~g} / \mathrm{l}$; cadmium (Cd), $154.3 \mu \mathrm{g} / \mathrm{l}$; copper (Cu), $5.2 \mu \mathrm{g} / \mathrm{l}$; lead (Pb), $15.2 \mu \mathrm{g} / \mathrm{l}$; chromium (Cr), $6.1 \mu \mathrm{g} / \mathrm{l}$; nickel (Ni), $154.0 \mu \mathrm{g} / \mathrm{l}$. Escherichia coli, staphylococci, enterococci, Salmonella and spores of Clostridium perfringens were detected in unstored urine samples, with $26 \%$ of fecal contamination rate. The time of storage (30 days) under sunlight was enough for almost all bacteria removal in urine samples. Although the fertilizing value of urine was confirmed, it would be important to take account of the best practices on applying in soils, because of the high TDS contents. Also, the risk linked to micropollutants in urine-based fertilizers could be negligible in view of low quantities. The results obtained in this study prove that after $\mathbf{3 0}$ days of exposure to sunlight urine collected via eco-toilet becomes bacteriologically sanitized, and can therefore be 
used to fertilize soils. However, it is necessary to demonstrate the inactivation of other groups of enteric microorganisms in human urine during storage.

\title{
Keywords
}

\author{
Human Urine, Storage, Hygienic Quality, Micropollutants, Enteric Bacteria, Fertilizer
}

\section{Introduction}

To date, about 2.5 billion individuals in the world have no access to adequate sanitation facilities [1]. The situation is more striking in Sub-Saharan Africa rural and peri-urban areas [2]. However, the resort to eco-toilets in developing countries constitutes an alternative to the lack of sanitation and high costs of mineral fertilizers. As insight, urine-diversion toilet is the most widespread ecological sanitation equipment in the world [3]. It allows by an appropriate technology to separate at the source, urine and faeces in order to be used as fertilizers [4]. Human urine contains nitrogen $(\mathrm{N})$, phosphorus $(\mathrm{P})$ and potassium $(\mathrm{K})$. Its nutrient contribution is also important that mineral fertilizers [5] [6]. Nevertheless, micropollutants such as heavy metals, hormones, pharmaceutical residues and pathogens can be excreted in urine [4] [7]. Urine treatment before its application in soils could be necessary to reduce health and environmental risks due to some contained compounds, especially when urine is collected in large-scale systems [3]. However, available technologies for urine treatment are complex and their costs are commonly considered to be prohibitive [8]. For the ecological sanitation system used in this study, the adopted urine treatment consists in storage in tanks, then exposure to sun for days [9]. Ambient temperature as well as urine intrinsic parameters would contribute to pathogen removal [10]-[12]. It is important to note that Ouagadougou is located in the Sudano-Sahelian climate zone characterized by minimum temperatures of $14^{\circ} \mathrm{C}$ $21^{\circ} \mathrm{C}$ and $33^{\circ} \mathrm{C}-42^{\circ} \mathrm{C}$ maximum, with a short rainy season (May to October) and a long dry season. The evaporative demand is very high and reaches $1900 \mathrm{~mm} /$ year [13]. Sahelian soils of Ouagadougou are relatively poor in organic matter and nutrients (N, P, K) [14]. Arid soils are most affected by salinization [3] [15].

Many works carried out in Burkina Faso on urine collected from sanitation systems were based on agronomic tests [9] [16]. However, aspects related to the health risks on using excreta-based fertilizers were not deeply studied and thus little documented. The objective of this study was to evaluate the hygienic quality of urine used as fertilizer in large-scale systems in Ouagadougou, Burkina Faso.

\section{Materials and Methods}

\subsection{Study Sites}

The ecological sanitation system implemented in peri-urban areas of Ouagadougou in Burkina Faso includes Eco-toilets built mainly in households (about eight hundred), storage sites of excreta after collection and farming sites where urine-based fertilizers are used to produce vegetables (e.g. cabbage, cucumber, lettuce, carrot...). Figure 1 below describes the flow of products in the system, from collection to the valorization in agriculture via the treatment by storage. In this study, we focused on urine, because of large volumes reused.

The eco-toilet (Urine Diversion Dry toilet, UDDT) is made of a device for separating at source, urine and feces. The urine is collected and stored in plastic jerry cans (20 liters) and then exposed to sunlight for 30 days.

For analysis, urine samples were collected from storage sites in the four sectors of Ouagadougou peri-urban areas (Figure 2).

\subsection{Sample Collection and Processing}

On sites, punctual sampling was performed in seventy-two (72) urine jerry cans in total, according to the standard method ISO 5667-11. The criterion to include one of jerry can for sampling was the time of filling from an eco-toilet which was between 7 and 14 days. For microbiological analysis, samples were taken in jerry cans before sunlight exposure (unstored samples). After 30 days of exposure, stored urine samples were taken. Samples (200 ml each) were taken aseptically into sterile polyethylene bottles, using a pipet controller. Then, separated urine samples were taken for chemical analyses. For this experiment, a volume of $500 \mathrm{ml}$ of each sample 


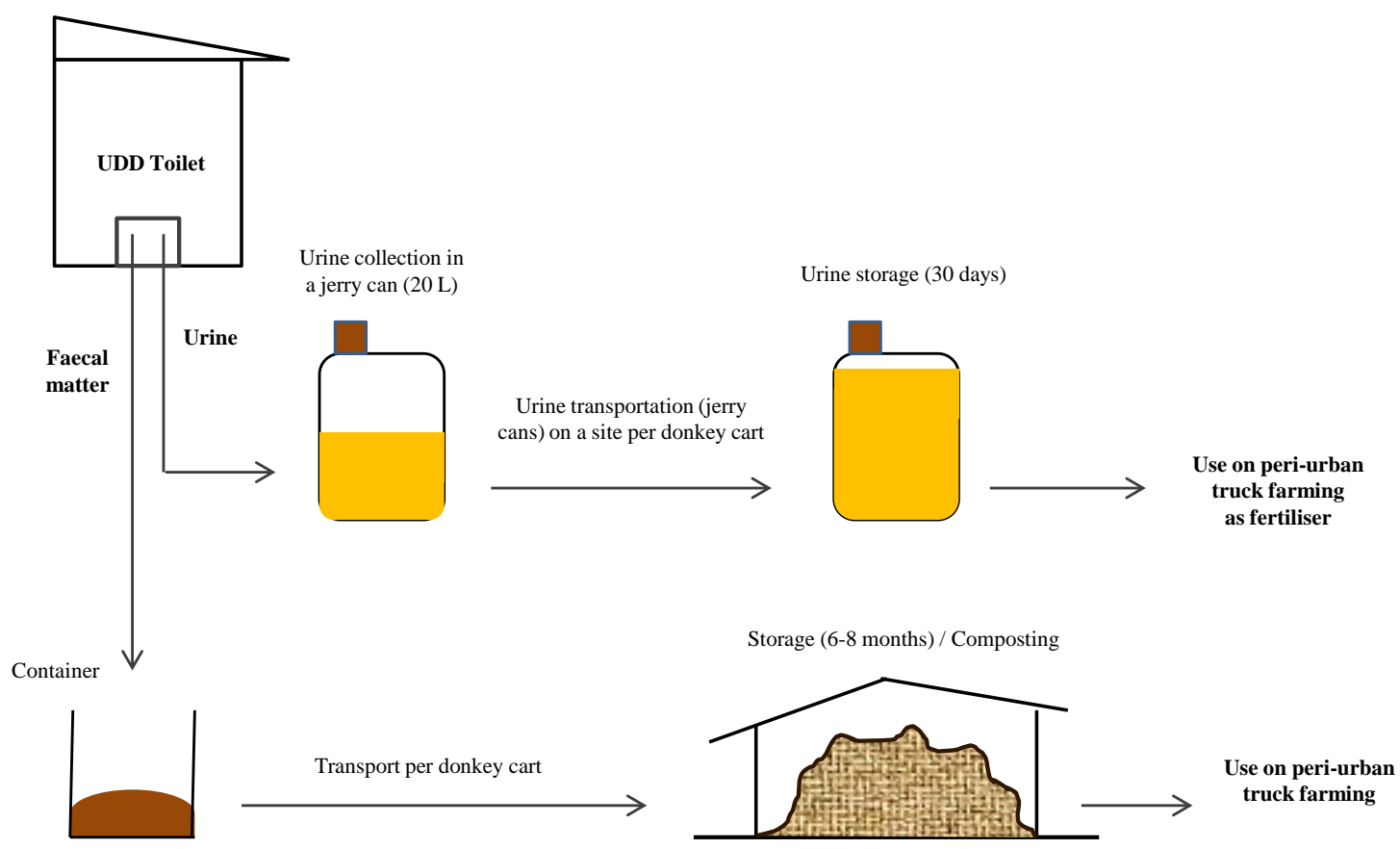

Figure 1. Flow of products (urine and feces) in the ecological sanitation system implemented in Ouagadougou.

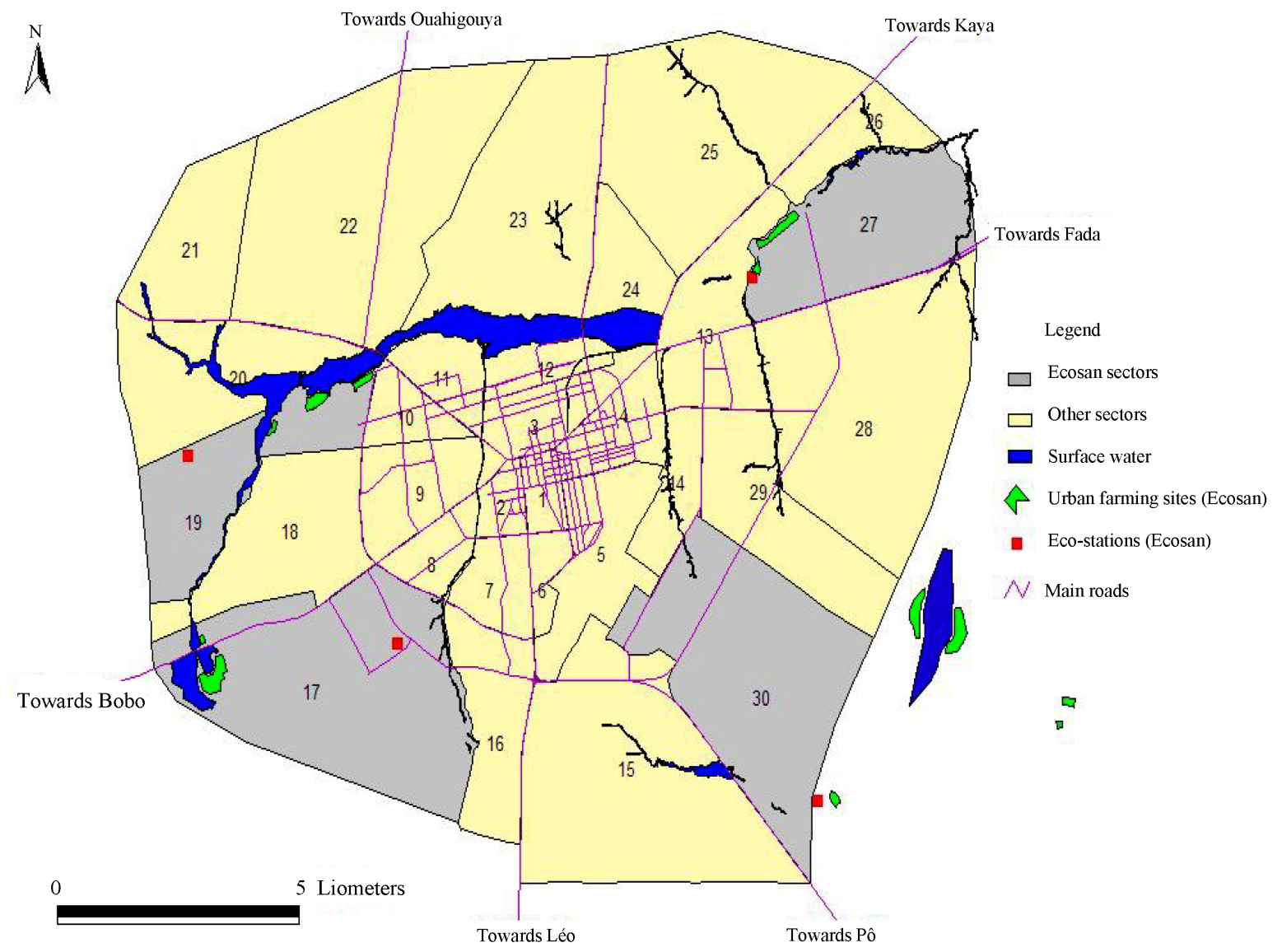

Figure 2. The four Ecological Sanitation Systems sectors (S17, S19, S27, S30) in Ouagadougou as well as the eco-stations or sites (red squares) and urban trucks farming (green stains) indicated. (Source: EU-EcoSan-Project, 2009). 
was collected into Pyrex brand borosilicate glass bottle in order to analyze nitrogen, phosphorus, potassium, total dissolved solids and heavy metals. Two (2) others composite samples (500 ml each) were taken from five urine jerry cans, for steroid hormones analysis. Centrifugated at $3000 \mathrm{~g}$ for 15 minutes, these two (2) composite samples were preserved at $-20^{\circ} \mathrm{C}$ until use. All other samples were preserved at $+4^{\circ} \mathrm{C}$ for less than 48 hours (microbial analysis) and more (chemical analysis). Sample collection was planned for a period of six (6) months (March-August 2011).

\subsection{Chemical Analysis}

The determination of $\mathrm{pH}$ was performed in situ, using a pH-meter WTW 340i (NF T 90 008). TDS concentrations in urine samples were determined by the measures of conductivity made by a conductimeter (WTW 340i) at $25^{\circ} \mathrm{C}$ as the reference temperature. Conductivity readings were converted in TDS ones by multiplication to a mathematical factor [17]. Ammonia nitrogen, phosphorus and potassium analyses were performed according to methods described by Rodier et al. [18]. For ammonia nitrogen, distillate obtained from $250 \mathrm{ml}$ urine sample was titrated with $0.1 \mathrm{~N}$ sulphuric acid. After mineralization of urine sample in the presence of sulphuric acid and sodium persulfate, then reaction with ammonium molybdate [18], phosphorus was measured using a molecular absorption spectrophotometer at $655 \mathrm{~nm}$ wavelength. Potassium was determined by the flame photometry method, using a photometer (AFP 100) according to the manufacturer's instructions. The concentrations of cadmium $(\mathrm{Cd})$, copper $(\mathrm{Cu})$, lead $(\mathrm{Pb})$, chromium $(\mathrm{Cr})$ and nickel $(\mathrm{Ni})$ in urine samples were determined with an atomic absorption spectrophotometer (Varian SpectrAA-220 FS). The wavelengths used for measurements were between $283.8 \mathrm{~nm}$ and $357.9 \mathrm{~nm}$. Steroid hormones (pregnandiol, estrone) were analysed in each centrifugated urine sample, using ELISA method as described by Deng et al. [19].

\subsection{Microbial Analysis}

For the enumeration of fecal coliforms and Escherichia coli in urine samples, Rapid'E. Coli 2 Agar (Difco) was used according to the standard method (AFNOR BRD 07/1-07/93). Enterococci and staphylococci were respectively enumerated in Slanetz \& Bartley Agar (Biokar) and Chapman Agar (Merck), with incubation at $37^{\circ} \mathrm{C}$ for 24 - 48 h [20]. Salmonella were detected in urine samples by ISO 6579 method, including three steps; preenrichment, enrichment and confirmation in Salmonella-Shigella-SS Agar (Biokar) and Xylose-Lysine-Désoxycholate-XLD Agar (Biokar) media. The spores of Clostridium perfringens were activated by heat $\left(80^{\circ} \mathrm{C}\right.$ for 10 minutes) and enumerated in Tryptone-Sulfite-Neomycine (TSN) Agar (Biokar), according to the standard method (NF V08-061).

\subsection{Data Analysis}

Geometric means, standard deviations, minimum and maximum values were calculated using XLSTAT 2008 statistical software.

\section{Results and Discussion}

\subsection{Chemical Parameters}

The results of $\mathrm{pH}$, TDS, ammonia nitrogen, phosphorus and potassium obtained are shown in the Table 1. In short, mean values of $\mathrm{pH}$ found in unstored and stored urine samples are respectively to 8.6 and 8.8. This low variation of $\mathrm{pH}$ values can be understandable; in fact urine was already alkaline during collection. It is well known that the main proportion of the nitrogen in urine is excreted as urea, which is transformed into ammonia in the collection tank and which increases the $\mathrm{pH}$ to $8.8-9.0$ [4]. Also, the alkaline $\mathrm{pH}$ is required to get substantial amount of ammonia in the uncharged state $\left(\mathrm{NH}_{3}\right)$, which the biocidal effect was previously proved [10] [11]. On comparing data, the concentrations of ammonia nitrogen in all urine samples did not great vary during the treatment by storage. However, as regards one unstored urine sample to other, the results show an important difference between minimum and maximum mean values of concentrations of ammonia nitrogen; $3.5 \mathrm{~g} / \mathrm{l}$ and 9.6 $\mathrm{g} / \mathrm{l}$ respectively. Likely, the low concentrations of ammonia nitrogen obtained, those corresponding to minimum values were due to the water additional in tank collection during the use of eco-toilets. Since, according to the technique used to collect the urine, it is clear that nitrogen losses by volatilization [21] should not be as important. Indeed, the collection of urine was made by diverting through a PVC pipe (polyvinylchloride). Adding wa- 
Table 1. Chemical parameters values in unstored and stored urine samples (30 days of storage in jerry cans exposed to sunlight).

\begin{tabular}{|c|c|c|c|c|c|c|c|c|}
\hline \multirow{2}{*}{ Site } & \multirow{2}{*}{$\mathbf{D} / \mathbf{p}$} & \multicolumn{2}{|l|}{$\mathbf{p H}$} & \multicolumn{2}{|c|}{ Ammonia-N (g/l) } & \multirow{2}{*}{$\begin{array}{c}\text { Total-P (g/l) } \\
\text { Stored }\end{array}$} & \multirow{2}{*}{\begin{tabular}{|l|} 
K (g/l) \\
Stored
\end{tabular}} & \multirow{2}{*}{$\begin{array}{c}\text { TDS (g/l) } \\
\text { Stored }\end{array}$} \\
\hline & & Unstored & Stored & Unstored & Stored & & & \\
\hline \multirow{3}{*}{ S17 } & Min & 8.3 & 8.7 & 3.8 & 3.7 & 0.26 & 1.82 & \\
\hline & Av & $8.6 \pm 0.2(10)$ & $8.7 \pm 0.1(10)$ & $6.4 \pm 1.2(10)$ & $6.3 \pm 1.3(10)$ & $0.27 \pm 0.00$ & $1.86 \pm 0.03$ & ND \\
\hline & Max & 8.7 & 8.9 & 8.5 & 8.7 & 0.28 & 1.89 & \\
\hline \multirow{3}{*}{ S19 } & Min & 8.6 & 8.8 & 3.5 & 3.5 & 0.29 & 1.87 & 12.9 \\
\hline & Av & $8.7 \pm 0.1(12)$ & $8.9 \pm 0.2(12)$ & $6.3 \pm 1.1(12)$ & $6.4 \pm 1.0(12)$ & $0.30 \pm 0.00$ & $1.91 \pm 0.03$ & $18.1 \pm 3.6(5)$ \\
\hline & Max & 8.8 & 8.9 & 7.8 & 7.7 & 0.31 & 1.95 & 24.9 \\
\hline \multirow{3}{*}{ S27 } & Min & 8.1 & 8.6 & 4.7 & 4,6 & 0.17 & 1.76 & 13.1 \\
\hline & Av & $8.4 \pm 0.1(15)$ & $8.8 \pm 0.1(15)$ & $7.6 \pm 1.1(15)$ & $7.6 \pm 1.0(15)$ & $0.19 \pm 0.02$ & $1.82 \pm 0.04$ & $25.2 \pm 6.9(5)$ \\
\hline & Max & 8.5 & 9.0 & 9.6 & 9.5 & 0.22 & 1.86 & 41.4 \\
\hline \multirow{3}{*}{ S30 } & Min & 8.5 & 8.8 & 5.5 & 5.4 & 0.17 & 1.79 & \\
\hline & Av & $8.7 \pm 0.1(7)$ & $8.9 \pm 0.1(7)$ & $7.5 \pm 1.2(7)$ & $7.4 \pm 0.9(7)$ & $0.18 \pm 0.01$ & $1.80 \pm 0.02$ & $\mathrm{ND}$ \\
\hline & Max & 8.8 & 9.0 & 9.2 & 9.0 & 0.21 & 1.88 & \\
\hline
\end{tabular}

D/p: dispersion parameters (Min = minimum; Av = average; Max = maximum) Mean value and its standard deviation (SD) are given with the number of samples in brackets ( ), ND: Not determined; TDS = Total Dissolved Solids.

ter in urine collection tanks, shows a bad use of any eco-toilets. Our observations corroborate these done by authors [4] [10] [22]. Also, the fact to keep urine in closed jerry cans may explain the almost constant concentrations of ammonia nitrogen during storage. This indicates the possibility of recovering nutrients in urine based-fertilizer after storage treatment. Indeed, $7 \mathrm{~g} / \mathrm{l}, 0.3 \mathrm{~g} / \mathrm{l}$ and $1.9 \mathrm{~g} / \mathrm{l}$ for nitrogen, phosphorus and potassium respectively were the mean values of concentrations obtained in stored urine (for 30 days). These results confirm the fertilizing potential of human urine [4] [5] [16]. On average, $21 \mathrm{~g} / \mathrm{l}$ was the concentration of TDS obtained in stored urine samples, with $12.5 \mathrm{~g} / \mathrm{l}$ and $41.6 \mathrm{~g} / \mathrm{l}$ as the extreme values. The concentrations of TDS are very high compared to the allowed limit values $(0.5-2 \mathrm{~g} / \mathrm{l})$ for the discharge of the effluents in soils [3]. It is already known that the accumulation of salts damage soils. That is why it is recommended to dilute urine-based fertilizer before application and more irrigation in order to limit the harmful effects of salinity [3].

The results of the analysis of heavy metals and steroid hormones in stored urine are represented in the Table 2.

The concentrations of cadmium $(\mathrm{Cd})$, copper $(\mathrm{Cu})$, lead $(\mathrm{Pb})$, chromium $(\mathrm{Cr})$ and nickel $(\mathrm{Ni})$ in stored urine were on average to $154.3 \mathrm{~g} / \mathrm{l}, 5.2 \mathrm{~g} / \mathrm{l}, 15.2 \mathrm{~g} / \mathrm{l}, 6.1 \mathrm{~g} / \mathrm{l}$ and $154 \mathrm{~g} / \mathrm{l}$ respectively. Unlike the $\mathrm{Cu}$ and $\mathrm{Cr}$, levels of $\mathrm{Cd}, \mathrm{Pb}$ and Ni obtained are higher than those in pure urine according [3]. Except the cadmium, concentrations of other heavy metals in stored urine samples are lower than these contained in faeces $(\mathrm{Cd}=62 ; \mathrm{Cr}=122 ; \mathrm{Cu}=$ $6667 ; \mathrm{Pb}=122 ; \mathrm{Ni}=450 \mathrm{mg} / \mathrm{kg}$ ) [3]. In view of our results, it is possible that urine analyzed were contaminated at the source, which may explain the high levels of heavy metals, especially the cadmium. It should be noted that the levels of heavy metals in human excreta are related to the food consumption. Vegetables eaten raw often have high levels of heavy metals; the main sources known are soils and organic fertilizers [23] [24]. Based on our results, the use of urine-based fertilizer does not represent a potential risk linked to heavy metals, since their contents are less than the allowable values of irrigated water in Burkina Faso [25]. The immunochemical method (ELISA) used to analyze steroid hormones in urine samples, allowed to obtain concentrations such as $<100 \mu \mathrm{g} / \mathrm{l}$ and $9 \mu \mathrm{g} / \mathrm{l}$ for pregnandiol and estrone respectively.

These values are superior to the detection limit of $0.5 \mathrm{ng} / \mathrm{l}$, for analyzing environmental samples [19]. In the absence of regulation on the occurrence of steroid hormones in effluents, it is difficult to compare our results to others. However, the rapid degradation of hormones in soils has been demonstrated [26]-[28]. To this end, the 
Table 2. Concentrations of heavy metals and steroid hormones in stored urine samples.

\begin{tabular}{|c|c|c|c|c|c|c|c|c|}
\hline \multirow{2}{*}{ Samples } & \multirow{2}{*}{$\mathrm{D} / \mathrm{p}$} & \multicolumn{5}{|c|}{ Heavy metals $(\mu \mathrm{g} / \mathrm{l})$} & \multicolumn{2}{|c|}{ Steroids ( $\mu \mathrm{g} / \mathrm{l})$} \\
\hline & & Cd & $\mathrm{Cu}$ & $\mathbf{P b}$ & $\mathrm{Cr}$ & $\mathbf{N i}$ & Pregnandiol & Estrone \\
\hline $\mathrm{n}=3$ & $\begin{array}{l}\text { Min } \\
\text { Av } \\
\text { Max }\end{array}$ & $\begin{array}{c}153.2 \\
154.3 \pm 0.7 \\
154.9\end{array}$ & $\begin{array}{c}5.1 \\
5.2 \pm 0.1 \\
5.3\end{array}$ & $\begin{array}{c}15.1 \\
15.2 \pm 0.1 \\
15.3\end{array}$ & $\begin{array}{c}5.4 \\
6.1 \pm 0.6 \\
6.9\end{array}$ & $\begin{array}{c}152.1 \\
154.0 \pm 1.3 \\
155.8\end{array}$ & ND & ND \\
\hline $\mathrm{n}=2^{*}$ & Av & ND & ND & ND & ND & ND & $<100$ & 9 \\
\hline
\end{tabular}

D/p: diversion parameters (Min = minimum; Av = average; Max = maximum); n: number of samples; $2^{*}$ : Two composite samples, each had been constituted from 5 jerry cans; ND: Not determined.

ecotoxicological risk due to hormones in the urine-based fertilizers would be negligible. The extension of the analysis in stored urine to pharmaceutical residues including synthetic hormones and other endocrine disrupting compounds is desirable.

\subsection{Microbial Analysis}

The results of bacteriological analysis in unstored and stored urine samples are indicated in the Table 3.

Bacterial analysis in unstored urine concerned samples from jerry cans which the filling time was between 7 and 14 days. Note that the sampling of urine collected from eco-toilets was planned on time (March to August) from one site to another, following this order S17, S19, S30, S27. Looking on the bacterial indicators such as fecal coliforms, Escherichia coli, enterococci, the contamination rates in unstored urine from each site are as follows: 4.2\% (S17), 12.5\% (S19), 23.5\% (S30) and 63.2\% (S27). Taking into account all unstored urine samples analyzed, we obtained on average $26 \%$ of contamination rate by fecal indicators.

The results show that on average the highest contamination rate was obtained in urine from site 27 (63.2\%), whereas the samples of the site 17 gave the lowest contamination rate (4.2\%). Based on that, we can argue that the urine collected from eco-toilets can be contaminated by enteric microorganisms. These observations corroborate those reported by the authors [4] [22]. Possible sources of urine contamination during uses of ecotoilets are faeces and environment through contaminated soil and water. To explain the low bacterial contamination rates and quantities, it is likely that the sanitation urine began in the collection tanks before storage under the combined effects of intrinsic $(\mathrm{pH}$, ammonia of urine) and extrinsic (temperature) parameters. Also, significant differences on contamination rates observed $(4 \%-63 \%)$ could be due to a seasonal factor (influence of the ambient temperature), since the urine collection on sites S17, S19, S30 took place in dry-hot season (March - June) while the urine collection on site S27 site has occurred during the wet season (June - August). Note that in the study area, the above two seasons are respectively showed by high $\left(40^{\circ} \mathrm{C}\right)$ and moderate $\left(30^{\circ} \mathrm{C}\right)$ temperatures. After 30 days of urine storage in jerry cans exposed to sunlight, the results were such that the limit of detection ( $0 \mathrm{CFU} / \mathrm{ml}$ ) was obtained for all bacteria counted before treatment by storage, except the spores of Clostridium perfringens. Considering the results obtained in urine samples from site (S27), the concentrations of fecal coliforms (960 CFU/ml), Escherichia coli (120 CFU/ml), staphylococci (708 CFU/ml), enterococci (2040 CFU/ml), spores of Clostridium perfringens $(490 \mathrm{CFU} / \mathrm{ml})$ in unstored urine become zeros after 30 days of storage, except those of spores of $C$. perfringens $(100 \mathrm{CFU} / \mathrm{ml})$. Storage conditions are to consider for the removal of enteric pathogens in urine-based fertilizers [10]-[12]. Also, apart of the time of urine storage, our analyses do not allow us to evaluate accurately determinant parameters to sanitize urine by storage.

\section{Conclusion}

This study showed that the treatment by storage enables removing bacteria and recovering nutrients contained in urine for reuse in agriculture. Although the fertilizing value of urine has been confirmed in view of amounts of nitrogen, phosphorus, potassium, however, it is important to comply with the best practices of their application in soils, to avoid the accumulation of salts due to the very high concentrations of TDS. The levels of heavy metals in urine-based fertilizers are low, below the tolerable values in wastewater, thereby risks linked to heavy metals in urine seem negligible. Fecal contaminations in urine are possible during collections from eco-toilets, so urine can contain in addition to bacteria, other enteric organisms (e.g. viruses, protozoa), for which it would be desirable to evaluate the survival potential in urine. 
Table 3. Bacterial analysis in unstored and stored urine samples.

\begin{tabular}{ccccccccc}
\hline & \multicolumn{9}{c}{ Mean quantities of bacterial (CFU/ml) } \\
\cline { 2 - 8 } Germs & \multicolumn{2}{c}{$\mathrm{S} 17(\mathrm{~N}=24)$} & \multicolumn{2}{c}{$\mathrm{S} 19(\mathrm{~N}=16)$} & \multicolumn{2}{c}{$\mathrm{S} 27(\mathrm{~N}=15)$} & \multicolumn{2}{c}{$\mathrm{S} 30(\mathrm{~N}=17)$} \\
\cline { 2 - 9 } & Unstored & Stored & Unstored & Stored & Unstored & Stored & Unstored & Stored \\
\hline FC & $100(4.2)$ & $0(0)$ & $250(12.5)$ & $0(0)$ & $960(66.5)$ & $0(0)$ & $1375(23.5)$ & $0(0)$ \\
Ec & $100(4.2)$ & $0(0)$ & $200(6.2)$ & $0(0)$ & $120(20)$ & $0(0)$ & $100(11.7)$ & $0(0)$ \\
Sta & $0(0)$ & ND & $0(0)$ & ND & $708(40)$ & $0(0)$ & $0(0)$ & ND \\
Ent & $0(0)$ & ND & $300(12.5)$ & $0(0)$ & $2040(60)$ & $0(0)$ & $0(0)$ & ND \\
Cp & ND & ND & ND & ND & $490(53.3)$ & $100(37.5)$ & ND & ND \\
Sal & - & ND & - & ND & $+(6.6)$ & - & - & ND \\
\hline
\end{tabular}

CFU: Colony-forming unit; +--: Presence/Absence of Salmonella FC: Fecal coliforms; Ec: Escherichia coli; Sta: staphylococci; Ent: enterococci; Cp: Clostridium perfringens; Sal: Salmonella; ND: Not determined; (\%): Each number in brackets is the frequency (\%) from the total of samples by site $(\mathrm{N})$ and them where bacteria were counted.

\section{Acknowledgements}

The authors are thankful to the Pan African Intergovernmental Agency, Water and Sanitation for Africa (WSA), for providing framework to carry out this research. We acknowledge the International Foundation for Science (IFS) for financial support partly.

\section{References}

[1] United Nations International Children's Emergency Fund/World Health Organization (2013) Progress on Drinking Water and Sanitation. World Health Organization, Geneva, 40.

[2] World Health Organization (2012) The United Nations Report on Global Analysis and Assessment of Sanitation and Drinking-Water, GLAAS. World Health Organization, Geneva, 112.

[3] World Health Organization (2006) Guidelines for the Safe Use of Wastewater, Excreta and Greywater, Volume 4, Wastewater Use in Agriculture, 196.

[4] Jönsson, H. and Vinnerås, B. (2007) Experiences and Suggestions for Collection Systems for Source-Separated Urine and Faeces. Water Science and Technology, 56, 71-76. http://dx.doi.org/10.2166/wst.2007.558

[5] Mnkeni, P.N.S., Kutu, F.R., Muchaonyerwa, P. and Austin, L.M. (2008) Evaluation of Human Urine as a Source of Nutrients for Selected Vegetables and Maize under Tunnel House Conditions in the Eastern Cape, South Africa. Waste Management \& Research, 26, 132-139.

[6] Pradhan, S.K., Pitkänen, S. and Heinonen-Tanski, H. (2009) Fertilizer Value of Urine in Pumpkin (Cucurbita maxima) Cultivation. Agricultural and Food Science, 18, 57-68.

[7] Winker, M., Tettenborn, F., Faika, D., Gulyas, H. and Otterpohl, R. (2008) Comparison of Analytical and Theoretical Pharmaceutical Concentrations in Human Urine in Germany. Water Research, 42, 3633-3640. http://dx.doi.org/10.1016/j.watres.2008.06.002

[8] Pronk, W. and Kone, D. (2010) Options for Urine Treatment in Developing Countries. Desalination, 251, 360-368.

[9] Richert, A., Gensch, R., Jönsson, H., Dagerskog, L., Stenström, T. and Bonzi, M. (2010) Food Security and Productive Sanitation: Practical Guideline on the Use of Urine in Crop Production. Sustainable Sanitation Practice, 3, 31-33.

[10] Vinnerås, B., Nordin, A., Niwagaba, C. and Nyberg, K. (2008) Inactivation of Bacteria and Viruses in Human Urine Depending on the Temperature and Dilution Rate. Water Research, 42, 4067-4074. http://dx.doi.org/10.1016/j.watres.2008.06.014

[11] Nordin, A., Nyberg, K. and Vinnerås, B. (2009) Inactivation of Ascaris Eggs in Source-Separated Urine and Faeces by Ammonia at Ambient Temperatures. Applied and Environmental Microbiology, 75, 662-667. http://dx.doi.org/10.1128/AEM.01250-08

[12] Chandran, A., Pradhan, S.K. and Heinonen-Tanski, H. (2009) Survival of Enteric Bacteria and Coliphage MS2 in Pure Human Urine. Journal of Applied Microbiology, 107, 1651-1657. http://dx.doi.org/10.1111/j.1365-2672.2009.04353.X

[13] Ouédraogo, E., Mando, A., Brussaard, L. and Stroosnijder, L. (2007) Tillage and Fertility Management Effects on Soil 
Organic Matter and Sorghum Yield in Semi-Arid West Africa.Soil and Tillage Research, 94, 64-74. http://dx.doi.org/10.1016/j.still.2006.07.001

[14] Thiombiano, L., Nébié, A.K., Semde, A. and Yago, K.J. (2000) Global Database on Soil: Advantages and Weaknesses of Knowledge and the Use of Soil Environments in Burkina Faso. In: FAO, Ed., Report on Soil Resources in the World, 36.

[15] Johnston, C.R., Vance, G.F. and Ganjegunte, G.K. (2013) Soil Property Changes Following Irrigation with Coalbed Natural Gas Water: Role of Water Treatments, Soil Amendments and Land Suitability. Land Degradation \& Development, 24, 350-362. http://dx.doi.org/10.1002/ldr.1132

[16] Dagerskog, L. and Bonzi, M. (2010) Opening Minds and Closing Loops-Productive Sanitation Initiatives in Burkina Faso and Niger. Sustainable Sanitation Practice No. 3, 4-11.

[17] International Organization of Legal Metrology, IOLM (1999) Recommendation No. 56 and the NIST: National Institute of Standards and Technology. Newspaper of Solution Chemistry, 20, 1991.

[18] Rodier, J., Bazin, C., Boutin, J.P., Chambon, P., Champsaur, H. and Rodi, L. (1996) Natural Waters, Residual Waters, Sea Water. Chemistry, Physicochemistry, Microbiology, Interpretation of the Results. 8th Edition, Dunod, Paris.

[19] Deng, A., Himmelsbach, M., Zhu, Q.Z., Frey, S., Sengl, M., Bucheberger, W., Niessner, R. and Knopp, D. (2003) Residue Analysis of the Pharmaceutical Diclofenac in Different Water Types Using ELISA and GC-MS. Environmental Science \& Technology, 37, 3422-3429. http://dx.doi.org/10.1021/es0341945

[20] American Public Health Association, APHA (2005) Standard Methods for the Examination of Water and Wastewater. 21st Edition, American Public Health Association, Washington DC.

[21] Gnagne, T., Konan, K.F., Coulibaly, S. and Koné, K. (2006) Nitrogenous and Sanitary Quality of the Urine Collected with the Aim of the Fertilization of Grounds. Notebooks of Public Health, 5, 66-75.

[22] Höglund, C., Vinnerås, B., Stenström, T.A. and Jönsson, H. (2000) Variation of Chemical and Microbial Parameters in Collection and Storage Tanks for Source Separated Human Urine. Journal of Environmental Science and Health, Part A, 35, 1463-1475. http://dx.doi.org/10.1080/10934520009377047

[23] Agbenin, J.O., Danko, M. and Welp, G. (2009) Soil and Vegetable Compositional Relationships of Eight Potentially Toxic Metals in Urban Garden Fields from Northern Nigeria. Journal of the Science of Food and Agriculture, 89, 4954. http://dx.doi.org/10.1002/jsfa.3409

[24] Agyarko, K., Darteh, E. and Berlinger, B. (2010) Metal Levels in Some Refuse Dump Soils and Plants in Ghana. Plant Soil and Environment, 56, 244-251.

[25] Ministry of Water and Environment, Burkina Faso (2001) Decree No. 2001-185/PRES/PM/MEE, Fixing the Standards of Pollutants in Air, Water and Soil. Ministry of Water and Environment, Burkina Faso.

[26] Colucci, M.S. and Topp, E. (2001) Persistence of Estrogenic Hormones in Agricultural Soils: 17R-Ethynylestradiol. Journal of Environmental Quality, 30, 2077-2080. http://dx.doi.org/10.2134/jeq2001.2077

[27] Mansell, J., Drewes, J. and Rauch, T. (2004) Removal Mechanisms of Endocrine Disrupting Compounds during Soil Aquifer Treatment. Water Science and Technology, 50, 229-237.

[28] Xuan, R., Lassengale, A.A. and Wang, Q.Q. (2008) Degradation of Estrogenic Hormones in a Silt Loam Soil. Journal of Agricultural and Food Chemistry, 56, 9152-9158. http://dx.doi.org/10.1021/jf8016942 